\title{
Phenothiazine Measurement
}

National Cancer Institute

\section{Source}

National Cancer Institute. Phenothiazine Measurement. NCI Thesaurus. Code C74695.

The determination of the amount of phenothiazine present in a sample. 